\title{
La métallurgie des origines : utilisation de la sensualité comme outil de maîtrise technique
}

\section{Philippe Andrieux}

\section{(2) OpenEdition \\ 12 Journals}

Édition électronique

URL : https://journals.openedition.org/tc/695

DOI : $10.4000 /$ tc. 695

ISSN : 1952-420X

Éditeur

Éditions de l'EHESS

\section{Édition imprimée}

Date de publication : 1 novembre 1992

ISSN : 0248-6016

Référence électronique

Philippe Andrieux, «La métallurgie des origines : utilisation de la sensualité comme outil de maîtrise technique », Techniques \& Culture [En ligne], 17-18| 1992, mis en ligne le 10 janvier 2006, consulté le 29 septembre 2022. URL : http://journals.openedition.org/tc/695; DOl : https://doi.org/10.4000/tc.695

Ce document a été généré automatiquement le 29 septembre 2022.

Tous droits réservés 
La métallurgie des origines : utilisation de la sensualité comme outil de maîtrise technique

Philippe Andrieux 